\title{
Nuclear RNase MRP processes RNA at multiple discrete sites: interaction with an upstream $G$ box is required for subsequent downstream cleavages
}

\author{
Robert Karwan, ${ }^{1}$ Jeffrey L. Bennett, and David A. Clayton \\ Department of Developmental Biology, Stanford University School of Medicine, Stanford, California 94305-5427 USA
}

\begin{abstract}
RNase MRP is a site-specific endoribonuclease that processes primer RNA from the leading-strand origin of mammalian mitochondrial DNA replication. It is present in active form as isolated from the nucleus, suggesting a bipartite cellular location and function. The relatively high abundance of nucleus-localized RNase MRP has permitted its purification to near homogeneity and, in turn, has led to the identification of protein components of this ribonucleoprotein. Analysis of the mode of RNA cleavage by nuclear RNase MRP revealed the surprising and unprecedented ability of the endonuclease to process RNA at multiple discrete locations. Substrate cleavage is dependent on the presence of a previously described G-rich sequence element adjacent to the primary site of RNA processing. Downstream cleavages occur in a distance- and sequence-specific manner.
\end{abstract}

[Key Words: Endoribonuclease; RNase MRP; RNA processing; site-specific cleavage]

Received February 11, 1991; revised version accepted April 4, 1991.

RNase MRP (mitochondrial RNA processing) is a ribonucleoprotein (RNP) that cleaves RNA from the mitochondrial displacement-loop region in a site-specific, endonucleolytic manner. Cleavage of the standard mitochondrial RNA substrate occurs at a single location (Chang and Clayton 1987a,b). This position was one of several RNA-to-DNA transition sites mapped by nuclease protection and primer extension analyses of mitochondrial nucleic acid isolates /Chang and Clayton 1985; Chang et al. 1985). These findings have been incorporated into a model that hypothesizes mitochondrial RNase MRP ( $\mathrm{mtMRP}$ ) as a key activity involved in the RNA processing events that regulate gene expression in concert with initiation of leading-strand DNA replication (Chang et al. 1987). The RNA component of RNase MRP is encoded by a nuclear gene (Chang and Clayton 1989; Topper and Clayton 1990a) that is an RNA polymerase III transcription unit (Chang and Clayton 1989; Topper and Clayton 1990a; E.F. Michelotti and D.A. Clayton, in prep.); this suggests an array of potential regulatory steps for mitochondrial biogenesis at the levels of nuclear transcription, RNP assembly and transport, and mitochondrial import (for review, see Clayton 1991).

Recently, it was discovered that human autoantisera (originally described as $\mathrm{Th}$ or To) recognize mtMRP, 7-2 ( $\mathrm{Th} / \mathrm{To}$ ), and 8-2 RNPs, indicating that all of these RNPs share at least one related epitope (Gold et al. 1989).

${ }^{1}$ Present address: Department of Molecular Genetics, Institute of Tumor Biology and Cancer Research, University of Vienna, Vienna, Austria.
These autoantisera were employed to establish that RNase MRP RNA, Th RNA, and 7-2 RNA are of identical sequence (Gold et al. 1989; Yuan et al. 1989).

The existence of RNase MRP at high abundance and in an apparently active form in the nucleus raises the important issue of a possible functional role in that cellular compartment iChang and Clayton 1987b; Topper and Clayton 1990a,b|. Here, we report a characterization of the mammalian nuclear RNase MRP (nuMRP) activity. Purification of nuMRP to near homogeneity using antiTh autoantibodies permitted analysis of the protein composition of nuMRP and identified a $40-\mathrm{kD}$ protein as the major anti-Th autoantigen. By employing our standard RNA substrate we have found that nuMRP has the unique ability to cleave the same RNA molecule at multiple site-specific positions.

\section{Results \\ Identification and purification of nuMRP}

A simple and rapid procedure, employing anti-Th sera as an analytical tool, was devised for the purification of nuMRP (see Materials and methods) and is based on two features of RNase MRP: (1) its specific sedimentation properties in nondenaturing glycerol gradients; and (2) the fact that RNase MRP RNA represents a primary RNA polymerase III transcription product and, hence, lacks a trimethylated cap structure (Chang and Clayton 19891 . 
Nuclear Dignam extracts (Dignam et al. 1983) were adsorbed on and eluted from DEAE-Sephacel, concentrated by Centricon centrifugation, and subjected to glycerol gradient sedimentation. Fractions were collected, and aliquots were immunoprecipitated by antiTh sera. The coprecipitated RNAs were 3 '-end-labeled and assayed by denaturing gel electrophoresis. Examples of the reproducible RNA profiles obtained using human or mouse nuclear extracts are shown in Figure 1, A and C, respectively. Greater than $95 \%$ of RNase MRP RNA is routinely immunoprecipitable as judged by RNA hybridization analyses (data not shown). Two peaks of nUMRP RNA were obtained following glycerol gradient sedimentation. nuMRP that sedimented at $20 \mathrm{~S}$, as determined by analysis of U5 small nuclear RNP (snRNP) sedimentation in parallel glycerol gradients, was devoid of full-size RNase P RNA or any smaller RNase P or RNase MRP RNA species (Fig. $1 B$ and $D$; data not shown). The second peak of nuMRP RNA cofractionated with RNase P RNA (as well as RNase P activity; see below). In this study we have focused on nuMRP alone. Routinely, fractions 2-4 (Fig. 1A and C) were pooled, rechromatographed on DEAE-Sephacel, adsorbed twice on anti- $\mathrm{m}_{3} \mathrm{G} / \mathrm{IgG} / \mathrm{Sepharose}$, and concentrated by Centricon centrifugation. The fractions were then centrifuged in a second glycerol gradient; Figure 1, B and D, depicts the total RNA content of the fractions of two such gradients for human and mouse nuMRP. Fractions sedimenting at $20 \mathrm{~S}$ contained a single RNA species of $\sim 270$ nucleotides that hybridized with the respective human or mouse antisense MRP RNA probe; no RNase MRP RNA was detected in fractions corresponding to the sedimentation of $\sim 270$-nucleotide RNA alone (data not shown). These data indicate that the eukaryotic nucleus contains a significant amount of full-length RNase MRP RNA, most if not all of which is assembled into anti-Th reactive RNPs. Moreover, this population of nuMRP does not contain any detectable RNase MRP RNA processed (or breakdown) product and is devoid of any RNase P RNA species, as well as any other detectable RNA.

\section{Identification of nu MRP-associated polypeptides}

Extracts, as well as purified nuMRP preparations depleted of proteins by SDS/guanidium thiocyanate/ phenol-chloroform extraction or SDS-proteinase $\mathrm{K}$ treatment, were used as an antigen source for anti-Th immunoprecipitations. No RNAs were found in the precipitates of protein-depleted extracts (data not shown). Whole-cell extracts were prepared, and immunoprecipitations with various sera were carried out. Among other

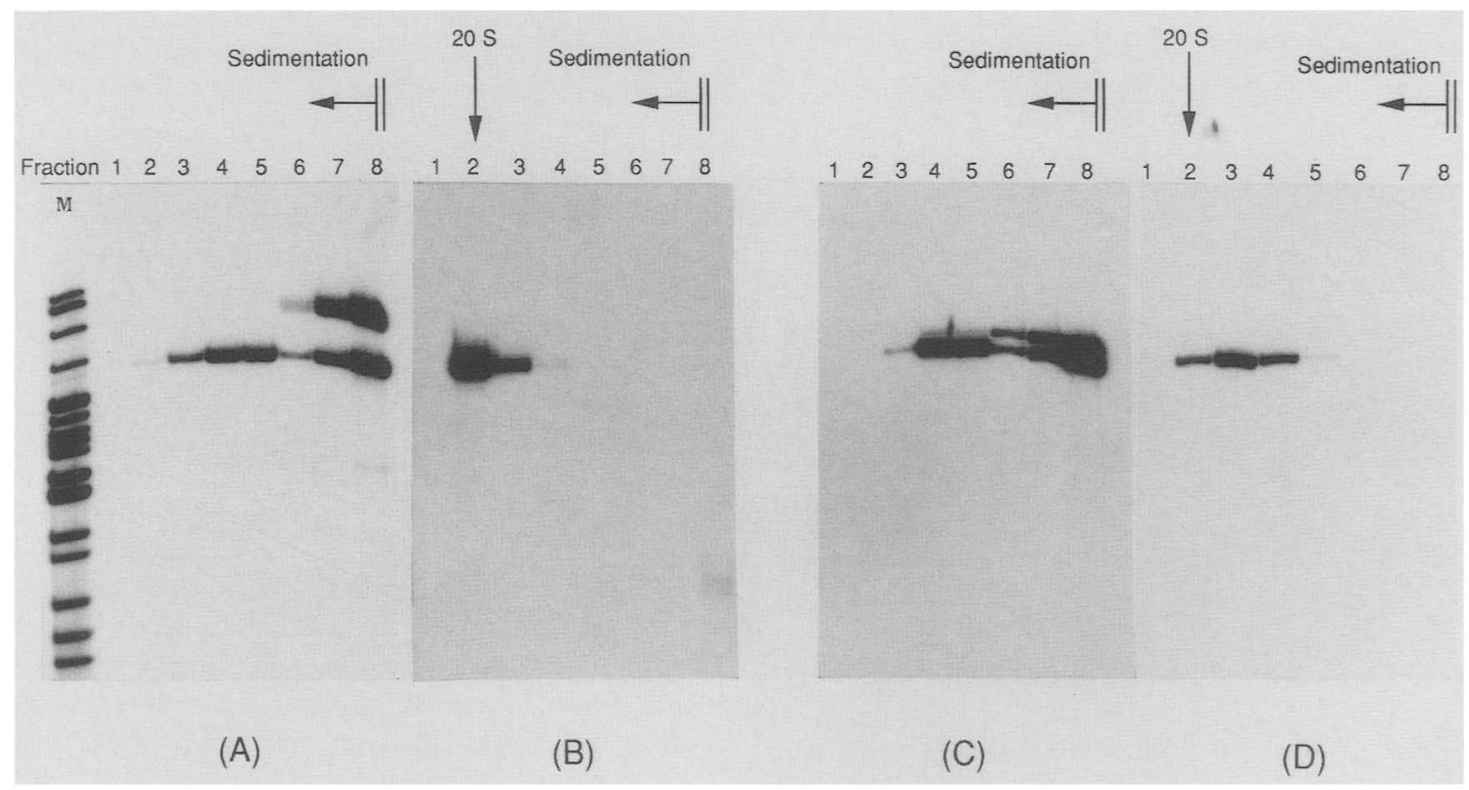

Figure 1. Separation of nuMRP RNPs by successive glycerol gradient sedimentation. (A) Human HeLa cell nuclear extract was fractionated by DEAE-Sephacel chromatography, followed by glycerol gradient sedimentation as described in Materials and methods. Aliquots (100 $\mu \mathrm{l} \mathrm{each)} \mathrm{of} \mathrm{individual} \mathrm{fractions} \mathrm{were} \mathrm{subjected} \mathrm{to} \mathrm{anti-Th} \mathrm{immunoprecipitation.} \mathrm{The} \mathrm{coprecipitating} \mathrm{RNA} \mathrm{was}$ 3 -end-labeled with $\mathrm{pCp}$ and analyzed on a $5 \%$ polyacrylamide $/ 7 \mathrm{M}$ urea gel. Fractions $2-4$ were pooled and further purified by chromatography on DEAE-Sephacel, followed by anti- $\mathrm{m}_{3} \mathrm{G} / \mathrm{IgG} /$ Sepharose, before resedimentation in a second glycerol gradient. RNase MRP RNA is the $\sim 270$-nucleotide species present in lanes 2-8. The larger RNA in lanes $6-8$ is RNase P H1 RNA. (B) Aliquots $\left(400 \mu \mathrm{l}\right.$ each) of the fractions of the second glycerol gradient were deproteinized, and the total RNA obtained was $3^{\prime}$-end-labeled and analyzed on a denaturing gel. ( $20 \mathrm{~S}$ ) The position of U5 snRNP as evidenced by Sm immunoprecipitation of fractions of parallel glycerol gradients (data not shown). Markers $(M)$ were Hpall-digested pBR322 DNA. ( $C$ and $D$ ) The same purification procedure was applied to mouse nuclear extracts. RNase MRP RNA is the smaller species in these lanes. Mouse RNase P RNA is assumed to be the slightly larger species in $C$ based on reproducible anti-Th precipitation and the presence of RNase $P$ activity in these fractions. 
lower relative molecular mass species a polypeptide of $40 \mathrm{kD}$ was detected in the anti-Th precipitates from extracts of both $\left[{ }^{35} \mathrm{~S}\right]$ methionine $/\left[{ }^{35} \mathrm{~S}\right]$ cysteine and $\left[{ }^{3} \mathrm{H}\right]$ leucine-labeled cells (data not shown). To determine whether these proteins copurified with nuMRP activity, human HeLa cells were subjected to pulse-chase labeling with $\operatorname{Tran}^{35} \mathrm{~S}$-label and nuMRP was purified as described above. Aliquots of every fraction of the second glycerol gradient were RNase $\mathrm{A} / \mathrm{micrococcal}$ nuclease-treated and analyzed by SDS-polyacrylamide gel electrophoresis followed by fluorography. About 10 polypeptides, ranging between 10 and $100 \mathrm{kD}$, were found in fraction 2 (Fig. 2). Most of these polypeptides were located in the fractions containing nuMRP RNA (see Fig. 1B, fraction 2). These proteins, especially the $40-\mathrm{kD}$ species observed consistently in anti-Th immunoprecipitates, are the potential components of nuMRP.

\section{NuMRP processes RNA at multiple sites}

Fractions obtained after successive glycerol gradient purifications were assayed for nuMRP activity using the

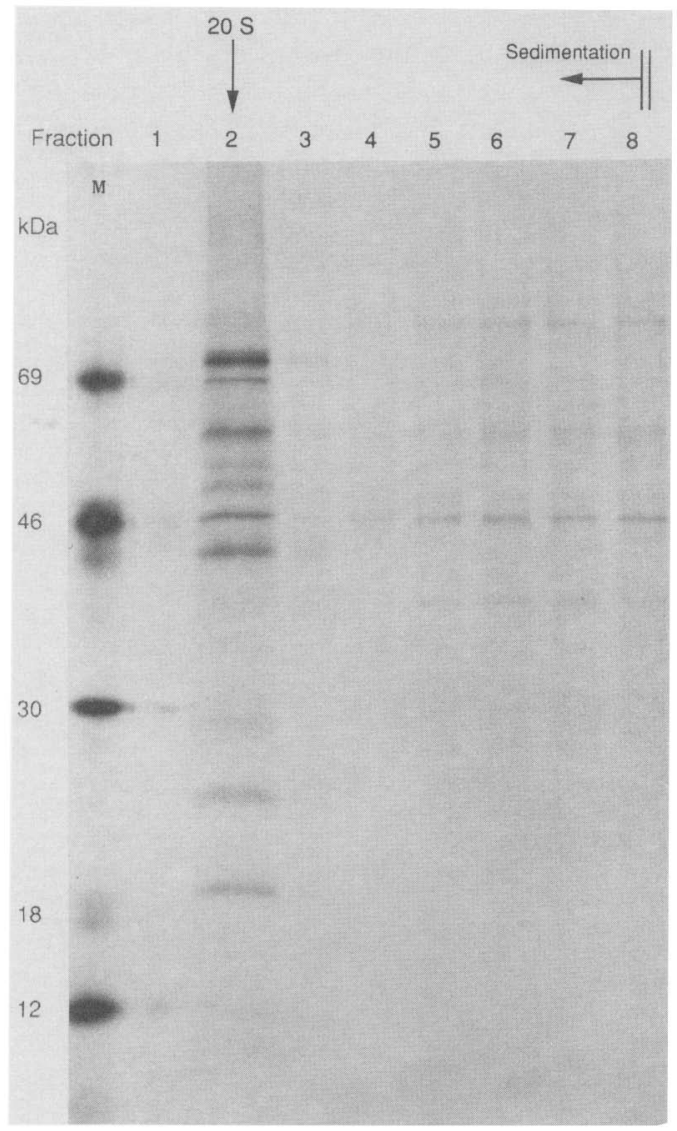

Figure 2. Identification of nuMRP polypeptides. HeLa cells $\left(2 \times 10^{8}\right)$ were pulse-chase-labeled with $\operatorname{Tran}^{35} \mathrm{~S}$-label. These cells were used for purification of nuMRP as in Fig. 1. Fractions from the final glycerol gradient were RNase treated, and the proteins were analyzed by SDS-gel electrophoresis and fluorography. (Lane $M$ ) The ${ }^{14} \mathrm{C}$-methylated molecular mass marker proteins: bovine serum albumin, ovalbumin, carboanhydrase, $\alpha$-lactoglobulin, and cytochrome $c$. standard mouse mitochondrial RNA substrate (Fig. 3). The decision to utilize this substrate was based on the following facts: (1) It was the substrate of the standard assay that defined the overall reaction conditions for RNase MRP (Chang and Clayton 1987a); (2) the exact positions of cleavage by human and mouse mtMRP on the wild-type substrate sequence are documented (Chang and Clayton 1987a,b; Bennett and Clayton 1990); (3) series of both deletion and point mutations of this substrate are available and have been characterized with respect to mtMRP cleavage (Bennett and Clayton 1990); and (4) there is no identified nuclear RNA substrate for RNase MRP.

Consistent with all previous analyses of mtMRP, nuMRP cleaved $5^{\prime}$ to a $\mathrm{G}$-rich sequence block resulting in a 130-nucleotide RNA product (site 1 cleavage). Surprisingly, two additional cleavage events were evident, resulting in products of $\sim 90$ (site 2 cleavage) and $\sim 30$ nucleotides (site 3 cleavage), respectively. High-resolution mapping of site 2 and 3 reaction products indicated that cleavages occurred within a canonical $5^{\prime}$ GNGNA-3' sequence (data not shown). Cleavages at all sites were found to be conserved evolutionarily between human and mouse, because purified mouse nuMRP (Fig. $3 \mathrm{~A} /$ exhibited the same multiple site specificity as human nuMRP (Fig. 3B) on the standard mouse RNA substrate.

Individual glycerol gradient fractions were assayed for nuMRP and RNase P activity (Fig. 3A). Those glycerol gradient fractions that contained both RNase MRP RNA and RNase P RNA (fractions 6-8) contained both RNase MRP and RNase P (as judged by pre-tRNA ${ }^{\text {Tyr }}$ cleavage activity). In addition, no pre-tRNA cleavage activity was present in fractions containing RNase MRP alone (fractions 3-5). These data indicate that (1) as expected, the presence of RNase P RNA is required for RNase P activity (Bartkiewicz et al. 1989), and (2) the presence of $\mathrm{Hl}$ RNA in nuMRP-containing fractions does not change the cleavage specificity of nuMRP; no cleavage occurs at any novel sites, nor is the full range of nuMRP cleavage affected by the presence of RNase P.

To investigate further the requirement for nuMRP in the downstream cleavage events, micrococcal nuclease inactivation and immunodepletion experiments were performed. Pooled peak fractions of nuMRP, purified through the second glycerol gradient, were preincubated with micrococcal nuclease or the appropriate controls and assayed for activity (Fig. 4A). Cleavage at each of the three sites was reduced equivalently with increasing concentrations of micrococcal nuclease in the preincubation step. In complementary experiments nuMRP was preincubated with anti-Th IgG, as well as normal human immunoglobulins, before performing standard activity assays. The data of Figure $4 \mathrm{~B}$ demonstrate the specific and concentration-dependent depletion of nuMRP activity by anti-Th IgG. Taken together, these results confirm that all endonuclease activities that copurify with nuMRP require an intact and functional nuMRP RNP because the loss of integrity of nuMRP RNA or the depletion of Th antigen inhibits all cleavage activity. 

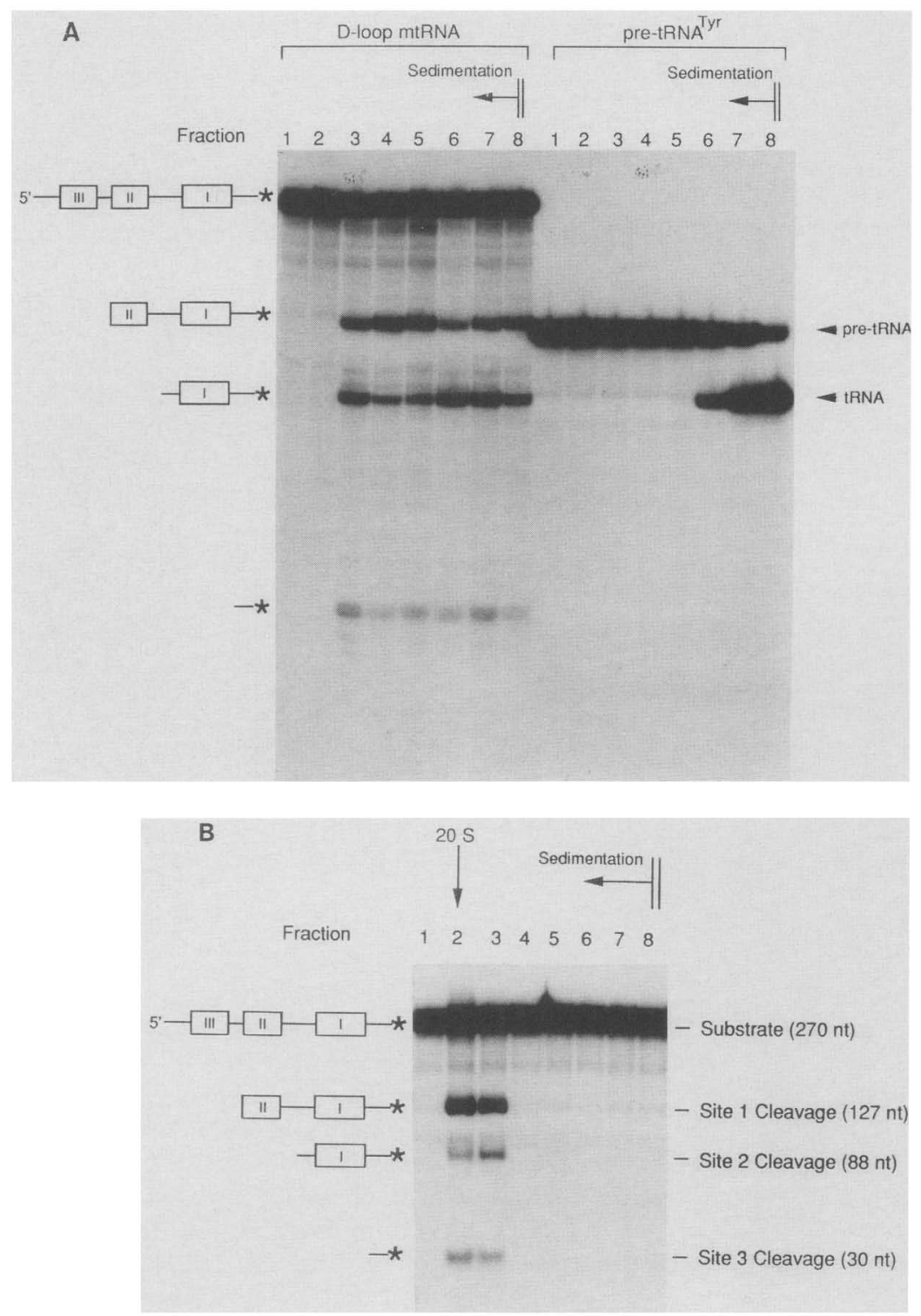

Figure 3. NuMRP copurifies with a multisite RNA-processing activity. (A) The fractions containing mouse nuMRP from the first glycerol gradient were tested individually $(2 \mu l$ each) for RNA processing activity as described in Materials and methods. 3 '-End-labeled standard substrates: mouse mitochondrial RNA (lanes 1-8, left); pre-tRNA ${ }^{\text {Tyr }}$ (lanes 1-8, right). The mouse RNA substrate, as well as the major cleavage products, are indicated at left with conserved sequence blocks I, II, and III /Chang and Clayton 1987a) depicted in boxes. The star denotes the 3 '-labeled end. The original substrate contains blocks I, II, and III. The labeled reaction product of site 1 cleavage contains blocks I and II. Cleavage at site 2 produces a labeled product with block I only; cleavage at site 3 produces a labeled product with no conserved sequence blocks. $(B)$ Individual fractions $(5 \mu l)$ of a second glycerol gradient from a human nuMRP preparation were tested with the mouse RNA substrate in standard assays. Substrate and product symbols are as in $A$, and the size of each species is noted at right.
A recent mutational analysis demonstrated that efficient site-specific cleavage depends on the interaction of mtMRP with two evolutionarily conserved mitochondrial sequences, conserved sequence blocks II and III (CSBII and CSBIII, respectively) (Bennett and Clayton 1990). In that study it was shown that an oligonucleotide spanning the CSBH/CSBIII region and, thus, a DNA sequence representation of the RNA substrate, was a potent competitive inhibitor of the cleavage reaction. As demonstrated in Figure 5, cleavage by nuMRP at all three sites was abolished in a concentration-dependent manner at nanomolar concentrations of the CSBII/CSBIII oligonucleotide. At these concentrations a control oligonucleotide had no detectable effect. The ability of the CSBII/CSBIII oligonucleotide to inhibit all three cleavage events reinforces the conclusion of the prior micrococcal nuclease and immunodepletion experiments: Functional
nuMRP is responsible for or involved in all three cleavage activities on the RNA substrate.

\section{Downstream cleavage is dependent on physical interaction with an upstream $G$ box}

A unique feature of nuMRP is that it is involved solitarily in multiple RNA-processing events. To begin to establish the basic reaction of nuMRP with substrate RNA, time course and mutational analyses were carried out. RNA was labeled at either the $3^{\prime}$ or $5^{\prime}$ end and incubated with various amounts of nuMRP (Fig. 6). If cleavages at each of the three sites were independent events of similar efficiency, all of the reaction products (depicted in Fig. 3B) should be apparent regardless of whether the RNA substrate was $3^{\prime}$ - or $5^{\prime}$-end-labeled. The $3^{\prime}$-end-labeled substrate yielded three cleavage prod- 


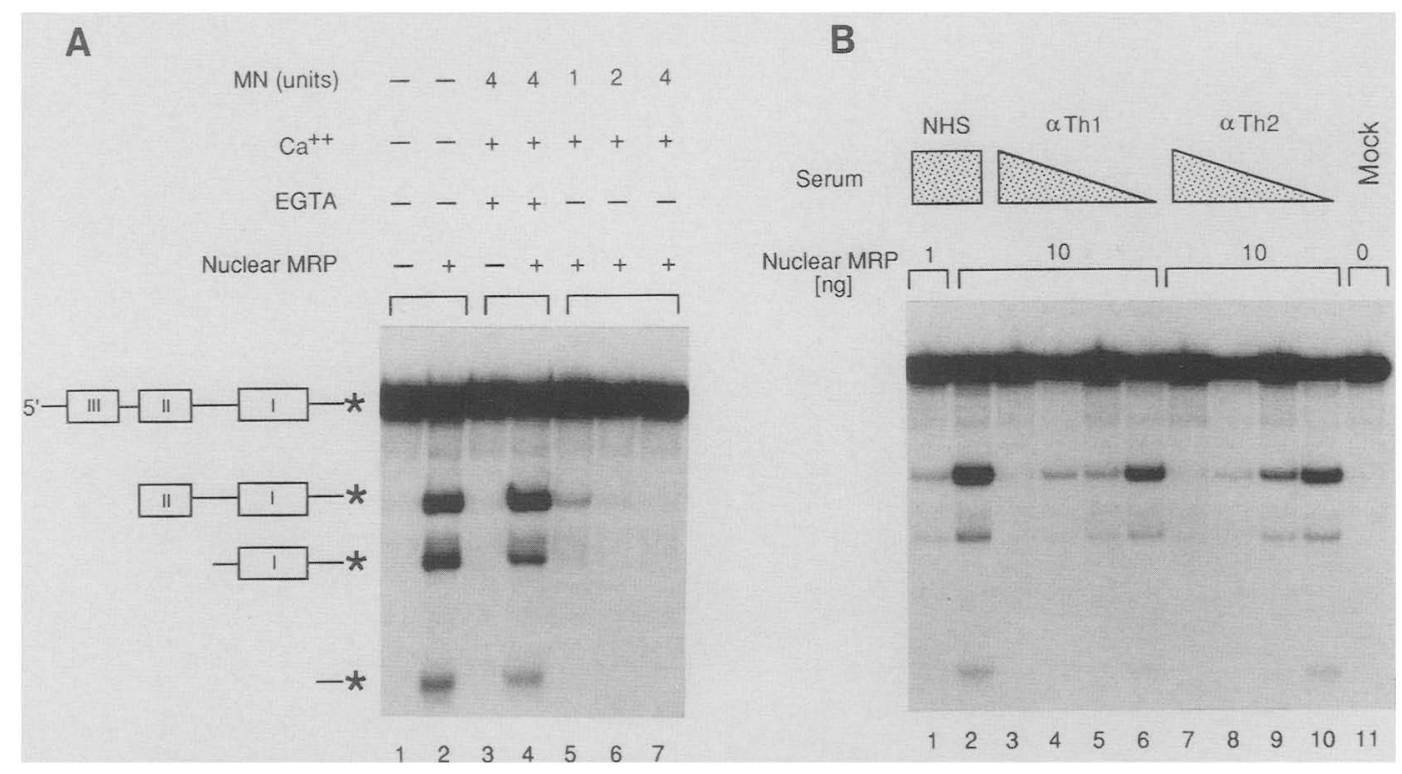

Figure 4. Multisite processing activity of nuMRP is intrinsic to the RNP. (A) Highly purified mouse nuMRP (Fig. 1D, $10 \mathrm{ng}$ ) was preincubated with micrococcal nuclease for $15 \mathrm{~min}$ at $37^{\circ} \mathrm{C}$. Control reactions were performed in parallel as indicated at top. After inactivation of the micrococcal nuclease by EGTA, standard RNase MRP cleavage assays were carried out. Substrate and product symbols are as in Fig. 3. (B) Mouse nuMRP (10 ng) was preincubated with various concentrations (2-0.002 $\mu$ l of serum each, in 10-fold serial dilutions) of anti-Th IgG immobilized to protein A-Sepharose and subsequently assayed for activity. Normal human immunoglobulins (NHS) were used in control reactions.

ucts, indicating that all three cleavage sites were recognized in an independent or, possibly, in a $5^{\prime} \rightarrow 3^{\prime}$ processive fashion. Cleavage of the $5^{\prime}$-end-labeled substrate, however, resulted in the exclusive generation of one radiolabeled product migrating at $\sim 140$ nucleotides (Fig. 6, lanes $7-10$, corresponding to cleavage at site 1 . No radioactive products of 182 or 240 nucleotides, corresponding to site 2 or 3 cleavage, respectively, were obtained. These data show that the additional cleavages at sites 2 and 3 occurred only on those RNA molecules that had been cleaved previously at site 1 . However, these data do not prove that site 1 cleavage per se is a prerequisite for cleavages at sites 2 and 3 .

Additional experiments were conducted to examine the relationship between the various cleavage products produced by nuMRP. Time course analysis of nuMRP activity showed no delay in the production of site 2 and 3 cleavage products relative to that of site 1 /data not shown). In addition, prolonged incubation of purified site 1 RNA cleavage product with nuMRP resulted in only trace cleavage of the input RNA, which is inconsistent with the amount of site 2 and 3 cleavage products produced in reactions containing the full-length RNA substrate (data not shown). Neither of these experiments supports a model whereby the multiple cleavage activity of nuMRP is due to association and reassociation of various RNA substrates with a single RNP. Multisite processing by nuMRP is likely due to the processive action of a single RNP or the action of multiple nuMRP particles on a single RNA moiety.

As noted, high-resolution mapping studies established that nuMRP site 2 and 3 cleavages occurred at two $5^{\prime}$-GNGNA-3' motifs that were located 40 and 95 nucleotides, respectively, downstream of site 1 . We assayed the requirement for any downstream sequence surrounding the additional cleavage sites by employing progressive 3'-deletion RNA substrates (Fig. 7A). Deletion of CSBII (5'-GGGGGUGGGGGGUUU-3') in substrate $\Delta 3^{\prime} 4$ abolished all processing activity (Fig. 7A, lane 10), suggesting that interaction with the nucleotides contained in this G box is critical for all RNase MRP processing. Surprisingly, more limited deletion of substrate RNA sequence and its replacement with pSP65 vector sequence led to new cleavages within the vector sequence, a portion of which was seen with some, but not all, 3'-deletion mutation RNAs. Close inspection of the pSP65 vector sequence revealed four occurrences of the sequence $5^{\prime}$-GNGNA-3', upon which nuMRP cleavage would potentially give rise to products of 174, 145, 91, and 16 nucleotides (see schematic diagram in Fig. 7A). Cleavage at the vector site 174 (v174), which encompasses the sequence 5'-GCGUA-3', was seen only with mutation $\Delta 3^{\prime} 28$ (Fig. 7A, lane 6). Cleavage at site vl45 (sequence $5^{\prime}$-GUGAA-3') occurred with mutation $\Delta 3^{\prime} 28$, as well as (much more prominently) with mutation $\Delta 3^{\prime} 15$ (Fig. 7A, lanes 6 and 8). No specific cleavages were seen at sites v91 or v16. Essentially the same results were obtained with human nuMRP (data not shown). Analysis of these additional processing events (active cleavage sites indicated in boldface italics, below) with respect to their distance from site 1 revealed that site v174 is located 85,38 , and 25 nucleotides downstream of 


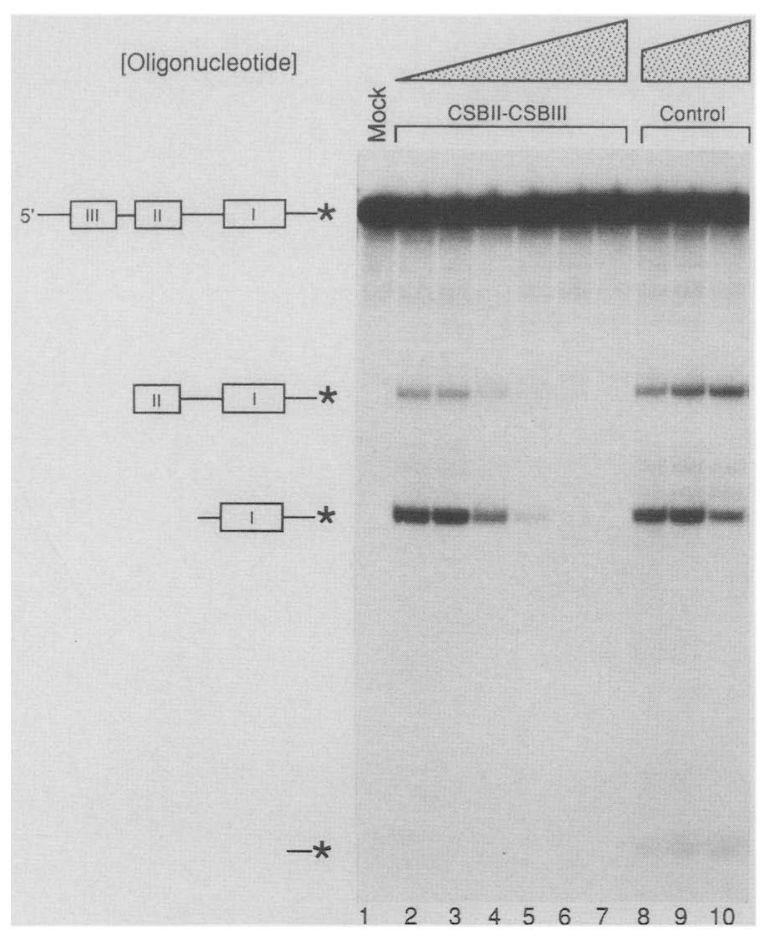

Figure 5. Oligonucleotide-mediated inhibition of nuMRP cleavages. The competitive oligonucleotide CSBI/CSBIII was included in the standard cleavage assays $10.2 \mathrm{ng}$ of mouse nuMRP| at concentrations of $0,0,5,15,45,138$, and $413 \mathrm{nM}$ (lanes 1-7, respectively). The sequence of this DNA oligonucleotide $\quad 5^{\prime}$-GTCTTTCAAGTTCTTAGTGTTTTTGGGGTTTGGCATTAAGAGGAGGGGGTGGGGGGTTTGGAGAGTTAT $-3^{\prime}$ ) is the same strand as that of the substrate RNA. The sequence of the control oligonucleotide is $5^{\prime}$-GCGTGGTTGGTGTGCCCCGAGTAAGAGTCGCGCCGA-3', and it was used at concentrations of 27,136, and $680 \mathrm{~nm}$ (lanes 8-10, respectively). Substrate and product symbols are as in Fig. 3 . The faint site 3 cleavage product in lane 2 is distinctly visible in the original autoradiogram.

site 1 in the mutations $\Delta 3^{\prime} 75, \Delta 3^{\prime} 28$, and $\Delta 3^{\prime} 15$, respectively; v145 is located 114,67 , and 54 nucleotides downstream of site 1 in those respective mutations. These data indicate that the additional processing by nuMRP depends on the occurrence of a $5^{\prime}$-GNGNA-3' motif; optimal cleavage also requires at least some minimal spacing between adjacent cleavage sites.

Depending on the respective 3 '-deletion mutation, an additional cleavage occurred 132-192 nucleotides downstream of site 1 , within the sequence $5^{\prime}$-CUGGGGUGCCUAAUGAGUGAGCU-3'. This sequence contains a truncated version of CSBII and six partially overlapping 5'-GNGNA-3'-motif point mutations (GNGNG, GNGNC, GNGNU; indicated in boldface italics, above). Cleavage at this site, however, was not conserved between human and mouse nuMRP (data not shown). In addition, as opposed to additional processing at all other sites described above, we noted little variability with regard to the extent of cleavage at this location within the various 3 '-deletion mutations (Fig. 7A). Cleavage was strictly dependent on CSBII and abolished upon its deletion (Fig. 7A, lane 10).

We then asked which nucleotides within the $G$ box are important for nuMRP multisite processing. Point-mutation substrate RNAs were selected that either increased (13C16C ; "up mutation"), decreased (13C17C, 14C16C; "down mutation"), or had no effect (17C) on mtMRP cleavage efficiency /see schematic drawing in Fig. 7B and legend for nomenclature) (Bennett and Clayton 1990). These substrates were incubated with nuMRP and an equal amount of wild-type 5'-end-labeled substrate, the latter serving as an internal control for cleavage efficiency (Fig. 7B). Similar to mtMRP, CSBII up/down mutations showed an increase/reduction of site 1 cleavage by nuMRP (lanes 6,8 , and 10). Interestingly, mutants $17 \mathrm{C}, 13 \mathrm{C} 17 \mathrm{C}$, and $14 \mathrm{C} 16 \mathrm{C}$ resulted in a concomitant decrease of site 2 and 3 products (lanes 4,6 , and 8 , respectively). With mutant $14 \mathrm{C} 16 \mathrm{C}$, which reduced site 1 cleavage 10-fold (and also slightly changed the exact cleavage site), cleavage products of sites 2 and 3 were reduced to almost background level (lane 8). Combined with the time course data (Fig. 6), the results with the mutated substrate RNAs show that the competence of nuMRP for additional downstream RNA processing is

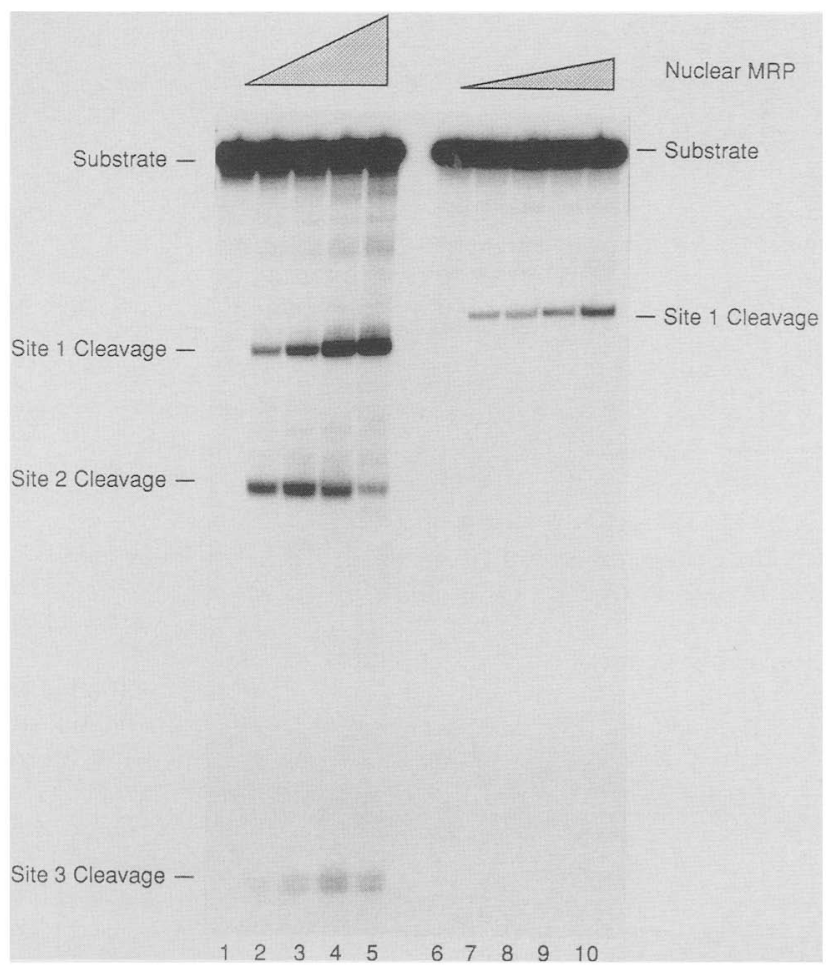

Figure 6. nuMRP cleavage at additional downstream sites is preceded by upstream cleavage at the G-rich sequence block. The mode of mouse nuMRP cleavage was analyzed by employing the mouse RNA substrate labeled at the $3^{\prime}$ end (left) or $5^{\prime}$ end (right), respectively. Increasing amounts of nuMRP $\mid 0,1,2$,

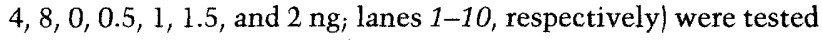
in standard RNase MRP cleavage assays. 


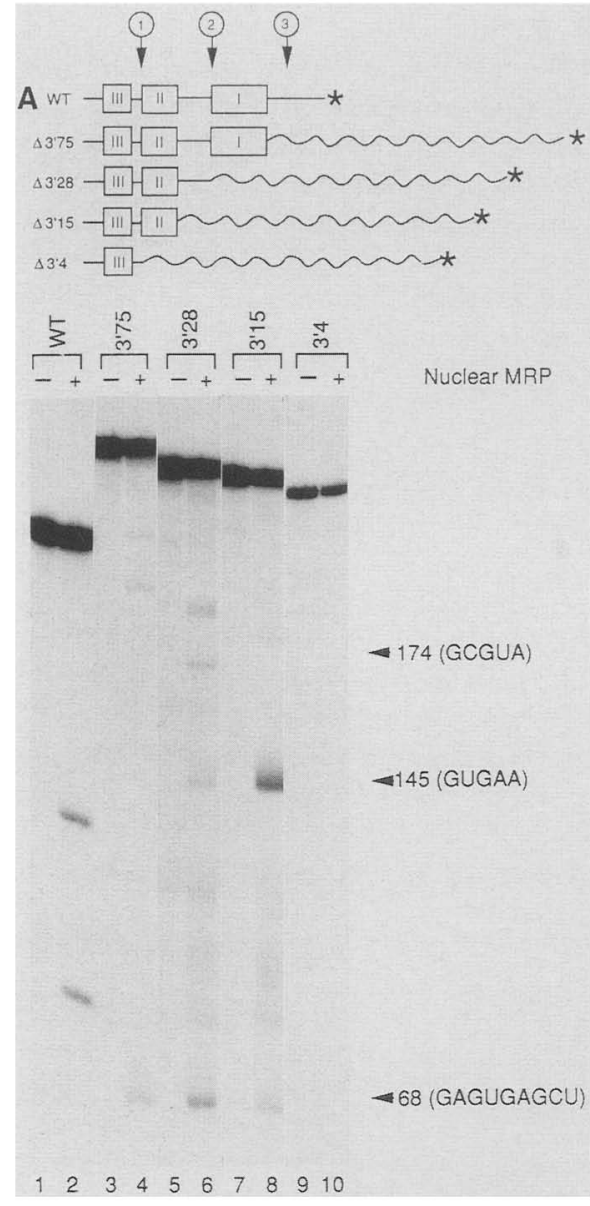

Figure 7. Mutational analysis of mouse nuMRP cleavage. $(A)$ Analysis of nuMRP cleavage by deletion mutagenesis of the standard substrate. Assays ( 2 ng of nuMRP) were performed with either $3^{\prime}$-end-labeled wild-type RNA substrate (lanes 1 and 2) or with the $3^{\prime}$-end-labeled deletion mutation substrates $\mid \Delta 3^{\prime} 75$, $\Delta 3^{\prime} 28, \Delta 3^{\prime} 15$, and $\Delta 3^{\prime} 4$; lanes $3-10$, respectively| under standard reaction conditions. The pSP65 plasmids, containing the $3^{\prime}$ truncated mitochondrial DNA inserts, were cleaved at their single $P$ vuII site in the vector prior to transcription in vitro. Vector sequence that replaces mitochondrial RNA sequence is symbolized by the wavy lines in the drawing at top. The names of the deletion clones refer to the number of nucleotides of mitochondrial sequence remaining $3^{\prime}$ of the primary RNase MRP cleavage site (site 1). The numbers at right (as well as the nucleotide sequences enclosed in parentheses next to these numbers) indicate the sites within the pSP65 RNA specifically cleaved by mouse nuMRP in these reactions. (B) Analysis of nuMRP cleavage on CSBII point-mutated substrate RNAs. Standard cleavage reactions contained $2 \mathrm{ng}$ of nuMRP, 5'-end-labeled wild-type RNA substrate (as an internal control for the cleavage efficiency), and 3 '-end-labeled point-mutated RNAs. The schematic at the top details the nucleotide positions of the various point mutations relative to the CSBII and CSBIII sequences. (C) Analysis of nuMRP catalysis on CSBIII point-mutated substrate RNAs. Standard cleavage reactions contained nuMRP and 3 '-end-labeled point-mutated RNAs. Lanes 3, 6, and 9 contained $10 \mathrm{nM}$ CSBII/ CSBIII oligonucleotide in the cleavage reaction. Substrate and product symbols are as in Fig. 3, except that the star denotes $3^{\prime}$ or $5^{\prime}$-end label in $B$ as indicated.

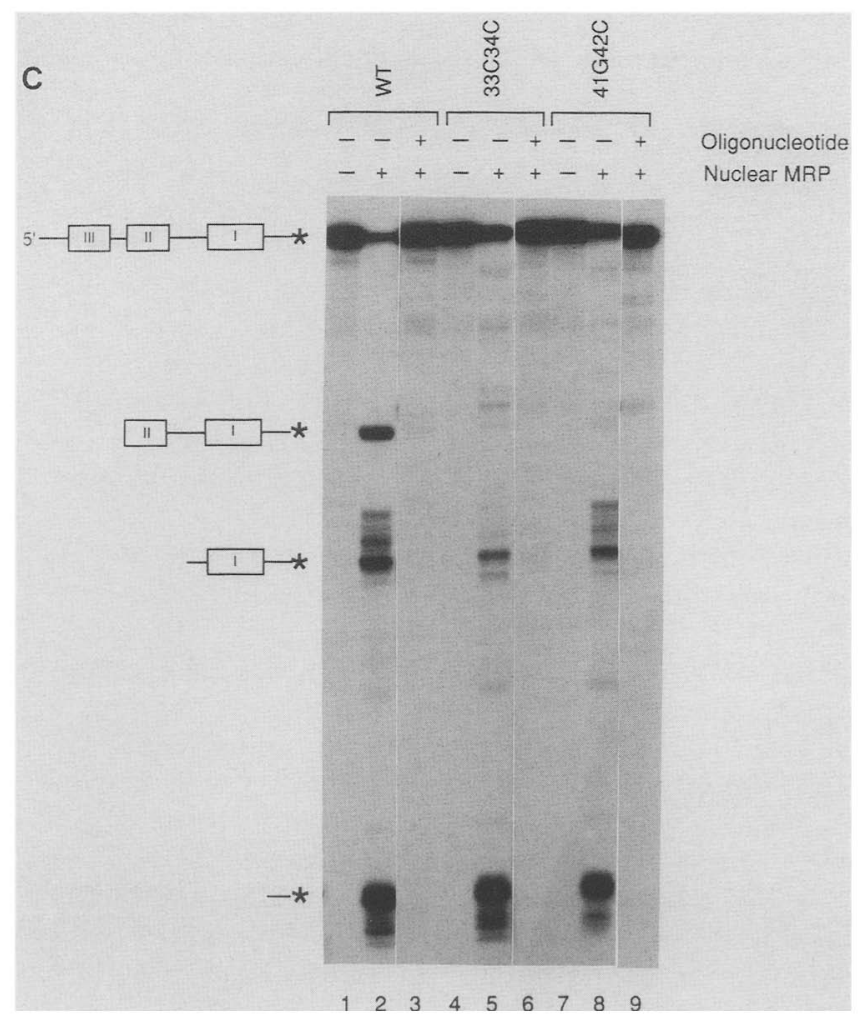


dependent on physical interaction (binding and/or cleavage) with a $\mathrm{G}$ box embedded within CSBII.

Point mutations in CSBIII have been shown previously to inhibit cleavage at site 1 by mtMRP (Bennett and Clayton 1990). The effect of CSBIII point mutations on the multiple cleavage activity of nuMRP was examined, using 3 '-end-labeled point-mutated substrate in a standard nuMRP cleavage assay (Fig. $7 \mathrm{C}$ ). As seen previously with mtMRP, mutations $33 \mathrm{C} 34 \mathrm{C}$ and $41 \mathrm{G} 42 \mathrm{C}$ (see Fig. $7 \mathrm{~B}$ and legend for nomenclature) exhibited no cleavage at site 1 (lanes 5 and 8). In contrast to point mutations in CSBII, no inhibition was found in site 2 or 3 cleavage (cf. Fig. 7C, lanes 5 and 8 with Fig. 7B, lanes 4, 6, and 8). The specific absence of site 1 cleavage in these mutant RNAs was verified using 5 '-end-labeled substrates; again, only site 2 and 3 cleavage products were observed (data not shown). Cleavages at sites 2 and 3, however, were still dependent on nuMRP activity, as the CSBII/CSBIII oligonucleotide specifically inhibited these cleavage events (lanes 3, 6, and 9). Therefore, additional RNA processing by nuMRP is not strictly dependent on cleavage at site 1 but requires the previous or concomitant binding/interaction of nuMRP RNP with the G-rich sequence block CSBII. In short, the G box must be present and recognized for any cleavages to occur, and processing at site 1 precedes downstream cleavages in RNA substrates that permit hydrolysis at site 1 . In addition, these results indicate that any substrate RNA refolding that might occur after site 1 cleavage is not a prerequisite for site 2 and 3 cleavages.

\section{Discussion}

Th antigenicity of nuMRP: Th40, a molecular link between RNase MRP and RNase P?

Upon sedimentation through glycerol gradients, nuMRP is resolved into two peaks of similar activity. Fractions at $20 \mathrm{~S}$ contain nuMRP and, upon further purification, no other RNA. In addition, some nuMRP copurifies with RNase P activity. Because of increasing amounts of various RNase MRP RNA and RNase P RNA fragments in fractions of lower sedimentation values, we have been unable to determine whether or not RNase P can be separated from nuMRP by our purification procedure. Moreover, employing the standard RNase MRP substrate, RNase P RNA-containing fractions of nuMRP yield an identical cleavage pattern to that produced by nuMRP alone. This suggests that if RNase $\mathrm{P}$ is able to cleave this substrate, processing does not occur at other sites not cleaved by nuMRP.

Upon sequence comparison of RNase MRP and RNase $P$ RNAs it was noted that the two share some limited stretches of similarity (Gold et al. 1989). Similar to the situation with U-series snRNPs, these RNAs may represent binding sites for related proteins (for review, see Mattaj 1989). It appears likely that any such related (evolutionarily conserved) proteins are part of the structure that triggers the anti-Th autoimmune response. A number of nuMRP polypeptides are potential candidates for both binding to MRP RNA and contributing to the Th autoimmune response, as they are found both in highly purified nuMRP and in Th immunoprecipitates.

It has been reported that antibodies raised against the Escherichia coli C5 protein /the protein component of bacterial RNase P) cross-react with a $40-\mathrm{kD}$ protein of partially purified human RNase $\mathrm{P}$; this antibody coprecipitated both RNase P H1 and MRP RNAs (Mamula et al. 1989|. It appears likely that this $40-\mathrm{kD}$ RNase P protein is related (or identical) to Th40, the major Th autoantigen. Th40 may bind to at least one of the four sequence blocks conserved between MRP and HI RNAs and facilitate the coprecipitation of MRP/H1 RNPs from crude cell extracts. One of these sites is related to the C5 protein-binding site on MI RNA of E. coli RNase P /Gold et al. 1989).

\section{Multisite RNA processing by an RNP}

Using our standard RNA substrate, as well as various deletion and point-mutational derivatives, we have begun to understand the basic processing mechanism of mammalian nuMRP. Cleavage by nuMRP occurs within 5'-GNGNA-3' sequence motifs that are spaced at $\sim 50$-nucleotide intervals; we note that not all possibilities for $\mathrm{N}$ have been assayed directly, but this motif is the simplest current possibility. Processing at each site on the RNA substrate requires previous or concurrent interaction of nuMRP with the G-rich sequence block; deletion and point mutations within it eliminate or reduce all cleavage activity. At least two possibilities could account for the observed phenomena (Fig. 8).

In the first model (Fig. 8, left), nuMRP is capable of $5^{\prime} \rightarrow 3^{\prime}$ scanning of an RNA molecule. In this model initial loading of nuMRP onto substrate RNA requires the presence of the G-rich sequence block. Following binding of nuMRP to the G box, RNA is cleaved at site 1 and nuMRP migrates down the substrate RNA restricted in its step size by its molecular dimensions. If nuMRP encounters a 5'-GNGNA-3' sequence, cleavage occurs and scanning continues.

It is interesting to note that the cleavage efficiency for downstream $5^{\prime}$-GNGNA-3' motifs, as determined by the 3'-deletion-mutated RNAs, varies slightly between human and mouse nuMRPs. The optimal average spacing for cleavage at $5^{\prime}$-GNGNA-3' is 46 or 56 nucleotides for human or mouse nuMRP, respectively. The human and mouse nuMRP RNAs differ in length by 9 nucleotides. Although such a coincidence could be entirely fortuitous, it may reflect part of the molecular dimensions of the RNP involved in a scanning-type mechanism.

In the second model (Fig. 8, right), binding of nuMRP at site 1 initiates a nucleation event for progressive nuMRP multimer formation. Upon initial nuMRP binding at the $G$ box, complex formation with another nuMRP molecule takes place such that the catalytic center of the latter becomes positioned $\sim 50$ nucleotides downstream of site 1. Binding of a downstream nuMRP moiety allows a subsequent RNP to bind, and multimer formation proceeds. If a $5^{\prime}$-GNGNA-3' sequence motif is present within a region of sequence that can be recog- 


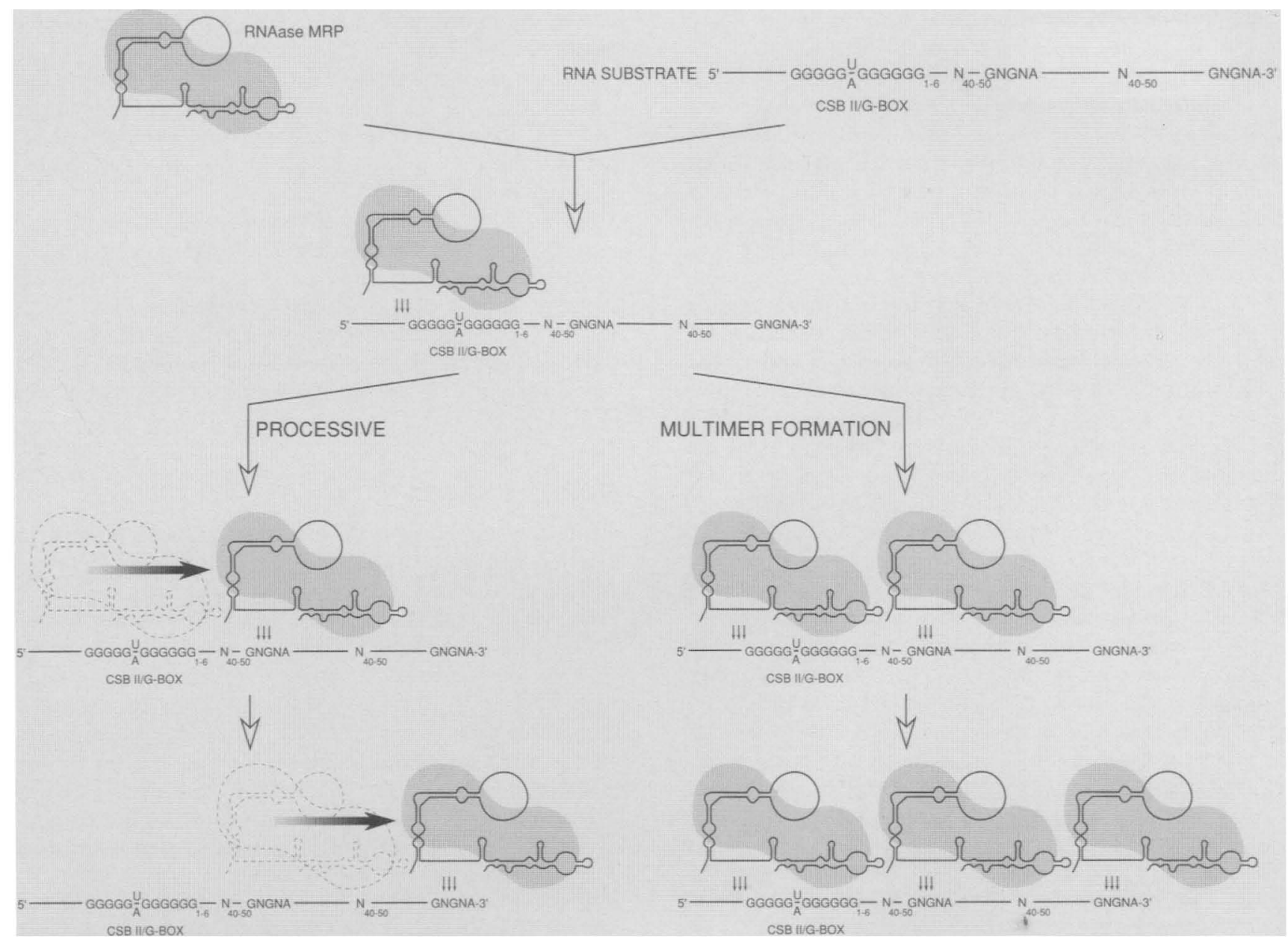

Figure 8. Potential models for the nuMRP cleavage mechanism. RNase MRP is shown in a form consistent with the available information on its structure. RNase MRP RNA is drawn in a form derived from the data of Topper and Clayton (1990b). The shaded area represents portions of MRP RNA that may be associated with proteins based on the availability of the unshaded sequences for oligonucleotide-mediated inhibition (Chang and Clayton 1987b; Topper and Clayton 1990a) and, possibly, substrate binding (Bennett and Clayton 1990). Interaction with an RNA substrate is shown under a procession model (left) or one in which multiple RNPs interact with one molecule of substrate (right; see text for details).

nized by the catalytic site of a bound RNP, then cleavage occurs.

We realize that our present mutational and time course analyses are unable to differentiate between the two models described above. Experiments designed to test directly the necessity of sequential site cleavage $(1>2>3)$ and enzyme processivity are currently being conducted.

The generation of multiple ordered and specific cleavages by a single RNP enzyme is both unique and intriguing. Although this RNP has only one RNA component, its protein composition is likely complex. This situation is reminiscent of the $20 \mathrm{~S}$ U5 snRNP which, in addition to U5 RNA, appears to contain 13 different polypeptides and may be involved in both steps of the splicing reaction (Bach et al. 1989; Winkelmann et al. 1989). The function of such RNPs may rely on their associated proteins, rather than the RNA, and we anticipate that the full spectrum of cellular RNase MRP function may de- pend on a large complement of protein components. Consistent with this notion, cellular RNA isolates as well as in vitro-synthesized MRP RNA have thus far failed to be catalytic in vitro (Topper and Clayton 1990b; R. Karwan and D.A. Clayton, unpubl.).

On the basis of in vitro complementation assays, a human protein factor, ASF/SF2, has recently been identified that influences $5^{\prime}$-splice site selection in premRNA splicing (Ge and Manley 1990; Krainer et al. 1990). Similarly, RNase MRP processing in the nucleus and mitochondria may depend on a different array of protein components. Multisite processing may occur with $\mathrm{mtMRP}$ in vivo and depend on one or more protein factor(s) easily dissociable from the enzyme; however, to date, the ability of mtMRP to cleave at any additional sites remains to be proved conclusively. It is clear that at least some preparations of mtMRP cleave only at site 1 (Chang and Clayton 1987a,b; Bennett and Clayton 1990). Mitochondrial import of RNase MRP is likely to be dif- 
ferent from the protein import pathway (Hartl and Neupert 1989). It is possible that regulatory RNase MRP protein factors, which may use the general protein import pathway independently, associate with mtMRP only transiently and are therefore not present in MtMRP isolates, which are subjected to an extensive purification protocol that begins with isolation of mitochondria. Multisite processing by nuMRP provides a complementation assay with which MRP-associated polypeptides might be identified biochemically, thereby suggesting a strategy to investigate the important and interesting question of whether nuMRP and mtMRP are distinct at the level of RNA-processing potential.

The likelihood and possible physiological significance of multisite processing in mitochondria are heightened by comparison of the sites of nuMRP cleavage with the previously mapped mouse mitochondrial RNA to DNA transition sites (Chang et al. 1985). Reminiscent of site 1 cleavage, cleavage at site 2 (nucleotide 16,061 of the mouse mitochondrial DNA sequence; Bibb et al. 1981) maps very near an in vivo RNA-DNA boundary (located at nucleotide 16,057$)$. Concomitant cleavages at sites 1 and 2 could provide a small RNA primer for DNA replication. Site 3 cleavage occurs at the downstream boundary of the major origin of mouse leading-strand mitochondrial DNA replication.

\section{Is nuMRP involved in nuclear $r R N A$ processing?}

The coisolation of the bulk of RNase MRP activity with the nuclear fraction strongly suggests that nuMRP is involved in nuclear RNA processing. Furthermore, identification of the major Th autoantigen, Th40, as an associated component of nuMRP and the strong nucleolar immunofluorescence produced by Th antisera may imply that nuMRP functions in certain aspects of ribosomal biogenesis, such as rRNA processing. Recently, it has been found that the abundant nucleolar U3 snRNP is involved in the first step of mammalian pre-rRNA processing: specifically, cleavage at the ETS sites and production of stable $45 \mathrm{~S}$ pre-rRNA precursor (Kass et al. 1990). The processing sites have not been mapped at the nucleotide level, and the involvement of other nucleolar snRNPs has not been excluded. Th antisera, however, do not affect processing in these $\mathrm{S} 100$ extracts.

Abundant G-rich sequence elements are present in eukaryotic rDNA sequences; however, there are no sequences with significant similarity to CSBIII. Point mutations in CSBIII inhibit cleavage by nuMRP at site 1 , adjacent to the G-rich sequence block, but do not affect processing at downstream sites 2 and 3 (see Fig. $7 \mathrm{C}$ ). Hence, nuMRP may cleave exclusively in the downstream 5'-GNGNA-3' sequences of potential nuclear pre-rRNA substrates. A G-rich sequence block in a nuclear RNA substrate could provide the initial binding site for nuMRP interaction (see Fig. 8); and in the absence of an upstream CSBIII-like element, catalysis would be limited to properly spaced 3'-cleavage motifs. We note that $5^{\prime}$-GNGNA-3' boxes, as well as a G box, are present $3^{\prime}$ to the in vivo-mapped ETS processing sites in a conserved region of both human and mouse pre-rRNAs (Kass et al. 1987). These downstream regions were found to be important for efficient processing at the upstream ETS sites in vitro (Craig et al. 1987). It will be of value to test whether or not nuMRP is involved in any of the processing reactions at these sites.

\section{Materials and methods}

Cell growth

Mouse LA9 or human HeLa cells were grown in suspension in minimum essential medium (MEM, Joklik modified; GIBCO) supplemented with glutamine, nonessential amino acids, penicillin/streptomycin, and $10 \%$ calf serum. Cells were split every $24 \mathrm{hr}$ by diluting 1 volume of the cell culture with 2 volumes of medium. Cell density was kept between $4 \times 10^{5}$ to $5 \times 10^{5} / \mathrm{ml}$ (LA9 cells) and $2 \times 10^{5}$ to $3 \times 10^{5} \mathrm{ml}$ (HeLa cells).

\section{Purification of nuMRP}

Nuclear extracts, prepared as described by Dignam et al. (1983), were the source for the purification of nuMRP. These extracts contain only a very minor portion of mitochondrial activities as judged by a specific tRNA assay (Topper and Clayton 1990a). All purification steps were carried out at $0-4^{\circ} \mathrm{C}$. All buffers were treated with $0.2 \%$ diethylpyrocarbonate (by stirring for $30 \mathrm{~min}$ ), autoclaved, and [with the exception of PBS $10.8 \% \mathrm{NaCl}, 0.02 \%$ $\left.\mathrm{KCl}, 10 \mathrm{mM} \mathrm{Na} 2 \mathrm{HPO}_{4}, 1.7 \mathrm{mM} \mathrm{KH} \mathrm{KO}_{4}\right)$ s supplemented, just before use, with dithiothreitol $(1 \mathrm{~mm})$ and 0.01 volume of $100 \times$ protease inhibitor stock. The $100 \times$ protease inhibitor stock was made by dissolving $10 \mathrm{mg}$ of chymostatin, $1.5 \mathrm{mg}$ of leupeptin, $7 \mathrm{mg}$ of pepstatin A, $850 \mathrm{mg}$ of phenylmethylsulfonyl fluoride, $500 \mathrm{mg}$ of benzamidine, and $5 \mathrm{mg}$ of aprotinin in $50 \mathrm{ml}$ of ethanol by stirring overnight. The solution was sterilized by microfiltration and kept at room temperature.

Cells $\left(2 \times 10^{8}\right.$ to $\left.20 \times 10^{8}\right)$ were harvested by centrifugation in a Beckman JA-10 rotor for $6 \mathrm{~min}$ at $2500 \mathrm{rpm}$, washed two to three times with PBS, and transferred to a sterile screwcap plastic tube for the final washes, which were done in a GLC-1 centrifuge for $5 \mathrm{~min}$ at $2000 \mathrm{rpm}$. Washed cells were resuspended in $5-10$ cell volumes of RSB (10 mM HEPES-KOH at $\mathrm{pH} 7.5,1.5$ $\mathrm{mM} \mathrm{MgCl} 2,10 \mathrm{mM} \mathrm{KCl}$ ) and swollen by incubation on ice, with several gentle inversions, for $10 \mathrm{~min}$. Cells were reharvested by centrifugation in the GLC-1 centrifuge and resuspended in 2 cell volumes of RSB. This suspension was then transferred to a Kontes Dounce homogenizer and lysed by 15 strokes with a $B$ pestle; nuclei were harvested by centrifugation (10 $\mathrm{min}$ at $2500 \mathrm{rpm}$ in a GLC-1 centrifuge). The supernatant was aspirated, and the nuclei were resuspended in 2 cell volumes of extraction buffer (20 mM HEPES-KOH at pH 7.5, $400 \mathrm{~mm} \mathrm{KCl}, 1.5 \mathrm{~mm} \mathrm{MgCl}$, $10 \%$ glycerol, $0.2 \mathrm{~mm}$ EDTA).

Extraction (15 min) was achieved by vortexing for $10 \mathrm{sec}$ at full speed, followed by 5 -min incubations on ice. The tubes were then shaken gently for an additional $15 \mathrm{~min}$, end over end, before centrifugation for $5 \mathrm{~min}$ (GLC-1 centrifuge at $2500 \mathrm{rpm}$ ). The supernatant was transferred to $1.5-\mathrm{ml}$ microcentrifuge tubes and cleared by centrifugation for $16 \mathrm{~min}$ at $16,000 \mathrm{rpm}$ in a JA-18.1 rotor. Nuclear extract was dialyzed against that volume of buffer $\mathrm{D}(20 \mathrm{~mm}$ HEPES-KOH at $\mathrm{pH} 7.5,1.5 \mathrm{~mm} \mathrm{MgCl}$, $0.2 \mathrm{~mm}$ EDTA, 10\% glycerol), which, at equilibrium (after $3 \mathrm{hr}$ of dialysis|, resulted in a $\mathrm{KCl}$ concentration of $150 \mathrm{~mm}$.

The dialysate was cleared by centrifugation in microcentrifuge tubes as described above and applied batchwise to DEAE- 
Sephacel, which was pre-equilibrated with $150 \mathrm{~mm} \mathrm{KCl}$ in buffer D $/ 2 \mathrm{mg}$ of protein $/ \mathrm{ml}$ column volume) in 15- $\mathrm{ml} \mathrm{screwcap}$ tubes. The tubes were shaken end over end for $15 \mathrm{~min}$ each. After centrifugation ( $1 \mathrm{~min}$ in a GLC-1 centrifuge at $2000 \mathrm{rpm}$ ), the supernatant was aspirated and the resin was washed twice by shaking for 5 min each with $150 \mathrm{mM} \mathrm{KCl}$ in buffer $\mathrm{D}$.

MRP RNP was eluted with 2 column volumes of $250 \mathrm{mM} \mathrm{KCl}$ in buffer $\mathrm{D}$. The eluate was concentrated in Centricon $\mathrm{C} 10$ tubes by centrifugation for $8 \mathrm{hr}$ at $8000 \mathrm{rpm}$ (JA-20 rotor). The concentrate was diluted to $1 \mathrm{ml}$ with $150 \mathrm{mM} \mathrm{KCl}$ in buffer D and concentrated in Centricon C100 tubes for $1-2 \mathrm{hr}$ at 4000 rpm (JA-20 rotor). Of this, $50-100 \mu \mathrm{l}(500 \mu \mathrm{g}-2 \mathrm{mg}$ of protein) was loaded onto $15-30 \%$ glycerol gradients $[150 \mathrm{~mm} \mathrm{KCl}$ in buffer D [minus glycerol)] and centrifuged for $24 \mathrm{hr}$ at 40,000 $\mathrm{rpm}$ in an SW41Ti rotor. Fractions were collected, and aliquots $(100-500 \mu \mathrm{l})$ were subjected to anti-Th immunoprecipitation analysis while the remainder were frozen in liquid nitrogen and stored at $-80^{\circ} \mathrm{C}$. Those fractions, which contained nuMRP but no RNase P RNA, were thawed, pooled, and purified by DEAESephacel chromatography as described above. The eluate was incubated by shaking end over end with anti- $\mathrm{m}_{3} \mathrm{G} / \mathrm{IgG} /$ protein $\mathrm{A} /$ Sepharose ( $1 \mathrm{ml}$ of DEAE eluate $/ 0.4 \mathrm{ml}$ column volume) in a microcentrifuge tube for $30 \mathrm{~min}$.

After centrifugation ( $2 \mathrm{~min}$ in a microcentrifuge), the supernatant was removed and adsorbed to another anti- $m_{3} \mathrm{G} / \mathrm{IgG} /$ protein A/Sepharose batch column as described above. The resulting supernatant was then centrifuged for $16 \mathrm{~min}$ at 16,000 rpm (JA-18.1 rotor) and, thereafter, concentrated in Centricon C100 tubes for 2-4 hr as described above. Fifty microliters of concentrate was diluted with $50 \mu \mathrm{l}$ of buffer D /containing $5 \mu \mathrm{g}$ of bovine serum albumin and $150 \mathrm{~mm} \mathrm{KCl}$ and applied to glycerol gradient centrifugation as described above, except that the gradient buffers contained $0.05 \mathrm{mg} / \mathrm{ml}$ of bovine serum albumin. Fractions were collected as described above, aliquoted, frozen in liquid nitrogen, and kept at $-80^{\circ} \mathrm{C}$.

For RNA, protein, and activity assays, fractions were thawed quickly in a $20^{\circ} \mathrm{C}$ water bath and refrozen in liquid nitrogen immediately after use. This procedure did not change the MRP immunoprecipitability or activity when repeated three times. These highly purified nuMRP fractions did not show any alteration in specific activity after 6 months of storage at $-80^{\circ} \mathrm{C}$.

\section{In vivo labeling of HeLa cells}

All manipulations were carried out under sterile conditions (laminar flow), and all solutions were prewarmed to $37^{\circ} \mathrm{C}$. HeLa cells were grown in suspension in MEM (Joklik modified) to a cell density of $2 \times 10^{5} / \mathrm{ml}$. Cells $\left(2 \times 10^{8}\right)$ were harvested by centrifugation (6 min at $2500 \mathrm{rpm}$ and $37^{\circ} \mathrm{C}$, in a JA-10 rotor), washed three times with MEM without cysteine and methionine or without leucine for labeling with $\operatorname{Tran}^{35} \mathrm{~S}$-label or $\left[{ }^{3} \mathrm{H}\right]$ leucine, respectively. The cells were resuspended in $20 \mathrm{ml}$ of the appropriate media $\left(10^{7}\right.$ cells $\left./ \mathrm{ml}\right)$, and $10 \mathrm{ml}$ of each cell suspension was transferred to a petri dish and incubated for 30 min at $37^{\circ} \mathrm{C}$. Afterwards, $5 \mathrm{mCi}$ Tran ${ }^{35} \mathrm{~S}$-label or $\left[{ }^{3} \mathrm{H}\right]$ leucine (supplemented with the respective nonradioactive amino acids to yield a sp. act. of $20 \mathrm{mCi} / \mathrm{mmole}$ ) was added and incubation was continued at $37^{\circ} \mathrm{C}$ for $8 \mathrm{hr}$.

For pulse-chase labeling of HeLa cells, the same protocol was used except that such labeling with $\operatorname{Tran}^{35} \mathrm{~S}$-label $(1000 \mathrm{Ci} /$ mmole/ was done for $30 \mathrm{~min}$ at $37^{\circ} \mathrm{C}$. Subsequently, the cells were transferred to a $250-\mathrm{ml}$ spinner flask and diluted with MEM to $4 \times 10^{5} / \mathrm{ml}$. Cell growth was then continued for another $8-14 \mathrm{hr}$ at $37^{\circ} \mathrm{C}$, which resulted in a final yield of $\sim 2 \times 10^{8}$ labeled cells.
Preparation of total HeLa cell extracts

All steps were carried out at $0-4^{\circ} \mathrm{C}$. Cells $\left(2 \times 10^{8}\right)$ were harvested by centrifugation for $5 \mathrm{~min}$ at $2000 \mathrm{rpm}$ (GLC-1). After three washes with PBS, the cell suspension was transferred to a sterile $15-\mathrm{ml}$ screwcap plastic tube, resuspended in 10 cell volumes of RSB, and swollen on ice for $10 \mathrm{~min}$ (with several gentle inversions|. After collection of the cells by centrifugation as described above, the supernatant was aspirated. Twenty cell volumes of RIPA II buffer $150 \mathrm{~mm}$ HEPES-KOH at $\mathrm{pH} 7.5,400$ $\mathrm{mM} \mathrm{NaCl}, 15 \mathrm{mM} \mathrm{MgCl} 2,10 \%$ glycerol, $1 \% \mathrm{NP}-40,0.5 \%$ sodium deoxycholate, $0.1 \%$ SDS, $1 \mathrm{mM} \mathrm{DTT}$, and $1 \times$ protease inhibitor stock) were added, and extraction was carried out by vortexing full speed for $10 \mathrm{sec}$ every $5 \mathrm{~min}$ for $15 \mathrm{~min}$. The lysate was then cleared twice by centrifugation in microcentrifuge tubes for $16 \mathrm{~min}$ at $16,000 \mathrm{rpm}$ (JA-18.1 rotor). The supernatants were pooled, aliquoted, frozen in liquid nitrogen, and kept for up to 3 months at $-80^{\circ} \mathrm{C}$ /without intermediate thawing) before immunoprecipitation analysis.

\section{Immunoprecipitations}

Of 90 sera with positive nucleolar staining (Reimer et al. 1988), 8 patient sera specifically coprecipitated both $\mathrm{Hl}$ and MRP RNAs | the RNA components of human RNase P (Bartkiewicz et al. 1989) and RNase MRP, respectively|, as evidenced by RNA protection and primer extension analysis (data not shown). No serum was found that precipitated either one of these RNAs exclusively, suggesting that the two RNP enzymes share at least one common epitope (Gold et al. 1989).

For the analysis of coprecipitating RNAs, immunoprecipitation was carried out as described (Karwan and Kindås-Müegge 1989). For the analysis of both RNA (after $\left[{ }^{32} \mathrm{P} \mid \mathrm{pCp}\right.$ labeling) and radiolabeled proteins from the same immunoprecipitation reaction, the following method was used. All procedures were done in microcentrifuge tubes at $0-4^{\circ} \mathrm{C}$ lexcept when stated otherwise). All buffers were treated with $0.2 \%$ diethylpyrocarbonate and autoclaved. Each washing cycle (for one tube) consisted of (1) addition of $800 \mu$ l of IPBG (20 mM HEPES-KOH at $\mathrm{pH} 7.5$, $500 \mathrm{~mm} \mathrm{KCl}, 0.1 \% \mathrm{NP}-40,0.25 \%$ gelatin, $1 \times$ protease inhibitor stock); (2) 10-sec vortexing at full speed; (3) 10-sec centrifugation in a microcentrifuge tube at room temperature; and (4) quantitative vacuum aspiration of the supernatants.

Preblocking Twenty microliters of a $50 \%$ (wt/vol) suspension of protein A-Sepharose (Pharmacia) in PBS /containing $0.1 \%$ sodium azide for storage at $4^{\circ} \mathrm{C}$ ) was employed per reaction. Total cell extract $\left(0.5-1 \mathrm{ml}\right.$ from $1 \times 10^{7}$ to $2 \times 10^{7}$ mocktreated, nonradioactive cells) or a $0.5-\mathrm{ml}$ glycerol gradient fraction was incubated with the protein A-Sepharose beads for $1 \mathrm{hr}$ by slow end-over-end rotation. After centrifugation for $1 \mathrm{~min}$ and aspiration, the pellet (PAS) was kept on ice for up to several hours.

Preclearing Pansorbin $1500-1000 \mu \mathrm{l}$ of a $10 \%$ suspension, Calbiochem) was transferred to another microcentrifuge tube, washed twice with IPBG by resuspension with a micropipette and centrifugation for $1 \mathrm{~min}$, and coupled to $5 \mu \mathrm{l}$ of rabbit control serum by mixing for $30 \mathrm{~min}$ at room temperature. After two washes with IPBG, $0.5-1 \mathrm{ml}$ of ${ }^{35} \mathrm{~S} /{ }^{3} \mathrm{H}$-radiolabeled extract (from $1 \times 10^{7}$ to $2 \times 10^{7}$ cells) was added to the Pansorbin-IgG and rotated end over end for $1 \mathrm{hr}$. The suspension was subsequently centrifuged for $3 \mathrm{~min}$, and the supernatant was transferred to a fresh tube and centrifuged for another $3 \mathrm{~min}$.

Immunoprecipitation The precleared extract was added to a fresh tube containing $50 \mu \mathrm{l}$ of $10 \%$ bovine serum albumin and 
$2 \mu \mathrm{l}$ of human autoimmune serum. End-over-end rotation was carried out for $1 \mathrm{hr}$. This solution was then added to the PAS tubes and rotated for $1 \mathrm{hr}$ before centrifugation for $10 \mathrm{sec}$. An aliquot of the supernatant was frozen in liquid nitrogen and kept as a control at $-80^{\circ} \mathrm{C}$. The residual supernatant was aspirated.

Washing The PAS-immunocomplex pellet was resuspended in $300 \mu \mathrm{l}$ of IPBG. This slurry was overlaid onto $800 \mu \mathrm{l}$ of $1 \mathrm{M}$ sucrose (in IPBG) in a fresh tube and centrifuged for $1 \mathrm{~min}$. The supernatant was aspirated to the interface. Two hundred microliters of $2 \mathrm{M}$ urea (in IPBG) was overlaid, and aspiration (down to the pellets) was carried out immediately. The pellet was then washed seven times with IPBG and once with PBS.

Extraction and purification of protein and RNA One hundred microliters of guanidium mix (prepared according to Maniatis et al. 1982) and $100 \mu \mathrm{l}$ of phenol were added to the washed pellet and vortexed, and incubation was carried out at $65^{\circ} \mathrm{C}$ for $5 \mathrm{~min}$. After cooling to room temperature, $100 \mu \mathrm{l}$ of chloroform was added. Extraction was carried out by mixing for $5 \mathrm{~min}$. The aqueous phase was re-extracted once with chloroform, and the organic phase was re-extracted once with $150 \mu l$ of water. Proteins were precipitated, purified, and analyzed on SDS gels as described (Karwan and Kindås-Müegge 1989). Fluorography was done with Enlightning according to the recommendations of the supplier (NEN). Gels were exposed with two screens for 3 days to 3 months. The RNA was precipitated overnight with ethanol $/ 0.3 \mathrm{M}$ sodium acetate and collected by centrifugation for 20 min. After washing once with $70 \%$ ethanol, the RNA was $3^{\prime}$-end-labeled using $10 \mu \mathrm{Ci}$ of $\left.5^{\prime} \cdot\right|^{32} \mathrm{P} / \mathrm{pCp}(3000 \mathrm{Ci} / \mathrm{mmole})$ in $50 \mathrm{mM}$ HEPES- $\mathrm{KOH}(\mathrm{pH} 7.5), 10 \mathrm{mM} \mathrm{MgCl}_{2}, 3 \mathrm{~mm}$ dithiothreitol, $3 \mu \mathrm{M}$ ATP, $0.5 \mathrm{U} / \mathrm{ml}$ of RNAguard (Pharmacia), and 0.05 $\mathrm{U} / \mathrm{ml}$ of T4 RNA ligase (Pharmacia). Incubation was on ice for 12-18 hr. RNA was purified by three rounds of precipitation with ethanol $/ 2.5 \mathrm{M}$ ammonium acetate in the presence of $10 \mu \mathrm{g}$ of tRNA carrier, redissolved in $10 \mathrm{~mm}$ EDTA ( $\mathrm{pH} 8.0$ ), $90 \%$ formamide, and $6.4 \%$ glycerol, boiled for $10 \mathrm{~min}$, chilled on ice, separated on $5 \%$ polyacrylamide $/ 7 \mathrm{M}$ urea gels, dried, and analyzed by autoradioagraphy. Exposure (with screen) was for $12 \mathrm{hr}$ to 2 weeks.

\section{Preparation of substrate RNAs}

Plasmid DNAs (50 $\mu \mathrm{g}$ each) were digested overnight with the appropriate restriction enzyme and purified by phenol-chloroform extraction and ethanol-sodium acetate precipitation. The following DNA templates (2-10 $\mu \mathrm{g}$ each) were used for in vitro transcription reactions with SP6 RNA polymerase according to Sambrook et al. (1989): FokI-digested pUC19::TyrT containing pre-tRNA ${ }^{\text {Tyr }}$ /Guerrier-Takada et al. 1988); Xbal-digested pMR718B (Chang and Clayton 1987a); PvuII-digested 3'-deletion mutations $\Delta 3^{\prime} 75, \Delta 3^{\prime} 53, \Delta 3^{\prime} 28, \Delta 3^{\prime} 15$, and $\Delta 3^{\prime} 4$ (Bennett and Clayton 1990); and XbaI-digested point mutations pMS17C, pMS13C16C, pMS13C17C, pMS14C16C, pMS33C34C, and pMS41G42C (Bennett and Clayton 1990). 5'- and 3 '-End labelings were done as described previously (Bennett and Clayton 1990). All labeled transcripts were purified by denaturing gel electrophoresis as described previously /Chang and Clayton 1987a).

nUMRP and RNase P cleavage assays

nuMRP cleavage reactions were carried out according to Chang and Clayton (1987a), except that $5000 \mathrm{cpm}$ of substrate RNA and 1 unit of RNAguard were used per reaction. RNase P cleavage reactions were carried out according to Guerrier-Takada et al. (1988).

\section{Miscellaneous}

Anti- $\mathrm{m}_{3} \mathrm{G} /$ protein $\mathrm{A} / \mathrm{Sepharose}$ was made by the coupling of mouse monoclonal anti- $\mathrm{m}_{3} \mathrm{G}$ antibodies to protein A-Sepharose (Pharmacia) using dimethylpimelimidate (Sigma) as described by Harlow and Lane (1988). High-resolution mapping of nuMRP cleavage sites was carried out as described by Chang and Clayton (1987a). Protein concentrations were estimated according to Bradford (1976).

\section{Acknowledgments}

We are grateful to $R$. Lührmann for his generous gift of anti$\mathrm{m}_{3} \mathrm{G}$ antibodies and to $\mathrm{S}$. Altman and C. Guerrier-Takada for the plasmid pUCI9::TyrT. We thank D.D. Chang and M.E. Schmitt for comments on the manuscript, E.F. Michelotti and J.N. Topper for discussions, and J.N. Doda for technical assistance. R.K. is indebted to A. Karwan for her encouraging support throughout the course of this work. This investigation was supported by grant NP-9P from the American Cancer Society and grant GM33088-20 from the National Institute of General Medical Sciences. R.K. was supported by the Fonds zu Förderung der Wissenschaftlichen Forschung in Österreich (FWF project J0301M and J0466-MED|. J.L.B. is a Medical Scientist Training Program Trainee of the National Institute of General Medical Sciences (GM07365-14).

The publication costs of this article were defrayed in part by payment of page charges. This article must therefore be hereby marked "advertisement" in accordance with 18 USC section 1734 solely to indicate this fact.

\section{References}

Bach, M., G. Winkelmann, and R. Lührmann. 1989. 20S small nuclear ribonucleoprotein U5 shows a surprisingly complex protein composition. Proc. Natl. Acad. Sci. 86: 6038-6042.

Bartkiewicz, M., H. Gold, and S. Altman. 1989. Identification and characterization of an RNA molecule that copurifies with RNase P activity from HeLa cells. Genes \& Dev. 3: 488-499.

Bennett, J.L. and D.A. Clayton. 1990. Efficient site-specific cleavage by RNase MRP requires interaction with two evolutionarily conserved mitochondrial RNA sequences. Mol. Cell. Biol. 10: 2191-2201.

Bibb, M.J., R.A. Van Etten, C.T. Wright, M.W. Walberg, and D.A. Clayton. 1981. Sequence and gene organization of mouse mitochondrial DNA. Cell 26: 167-180.

Bradford, M.M. 1976. A rapid and sensitive method for the quantitation of microgram quantities of protein utilizing the principle of protein-dye binding. Anal. Biochem. 72: 248254.

Chang, D.D. and D.A. Clayton. 1985. Priming of human mitochondrial DNA replication occurs at the light-strand promoter. Proc. Natl. Acad. Sci. 82: 351-355.

- 1987a. A novel endoribonuclease cleaves at a priming site of mouse mitochondrial DNA replication. EMBO $I$. 6: 409-417.

- 1987b. A mammalian mitochondrial RNA processing activity contains nucleus-encoded RNA. Science 235: 11781184.

1989. Mouse RNAase MRP RNA is encoded by a nuclear 
gene and contains a decamer sequence complementary to a conserved region of mitochondrial RNA substrate. Cell 56: $131-139$.

Chang, D.D., W.W. Hauswirth, and D.A. Clayton 1985. Replication priming and transcription initiate from precisely the same site in mouse mitochondrial DNA. EMBO f. 4: 15591567.

Chang, D.D., R.P. Fisher, and D.A. Clayton. 1987. Roles for a promoter and RNA processing in the synthesis of mitochondrial displacement-loop strands. Biochim. Biophys. Acta 909: 85-91.

Clayton, D.A. 1991. Nuclear gadgets in mitochondrial DNA replication and transcription. Trends Biochem. Sci. 16: 107111.

Craig, N., S. Kass, and B. Sollner-Webb. 1987. Nucleotide sequence determining the first cleavage site in the processing of mouse precursor rRNA. Proc. Natl. Acad. Sci. 84: 629633.

Dignam, J.D., R.M. Lebovitz, and R.G. Roeder. 1983. Accurate transcription initiation by RNA polymerase II in a soluble extract from isolated mammalian nuclei. Nucleic Acids Res. 11: $1475-1489$.

Ge, H. and J.L. Manley. 1990. A protein factor, ASF, controls cell-specific alternative splicing of SV40 early pre-mRNA in vitro. Cell 62: 25-34.

Gold, H.A., J.N. Topper, D.A. Clayton, and J. Craft. 1989. The RNA processing enzyme RNase MRP is identical to the Th RNP and related to RNase P. Science 245: 1377-1380.

Guerrier-Takada, C., A. van Belkum, C.W.A. Pleij, and S. Altman. 1988. Novel reactions of RNase $P$ with a tRNA-like structure in turnip yellow mosaic virus RNA. Cell 53: 267272.

Harlow, E. and D. Lane. 1988. Antibodies: A laboratory manual. Cold Spring Harbor Laboratory, Cold Spring Harbor, New York.

Hartl, F.U. and W. Neupert. 1989. Import of proteins into the various submitochondrial compartments. J. Cell Sci. (suppl.) 11: $187-198$.

Karwan, R. and I. Kindås-Mügge. 1989. Identification of a yeast ribonuclease $\mathrm{H}$ as an $\mathrm{Sm}$ antigen. Eur. J. Biochem. 179: 549555.

Kass, S., N. Craig, and B. Sollner-Webb. 1987. Primary processing of mammalian rRNA involves two adjacent cleavages and is not species specific. Mol. Cell. Biol. 7: 2891-2898.

Kass, S., K. Tyc, J.A. Steitz, and B. Sollner-Webb. 1990. The U3 small nucleolar ribonucleoprotein functions in the first step of preribosomal RNA processing. Cell 60: 897-908.

Krainer, A.R., G.C. Conway, and D. Kozak. 1990. The essential pre-mRNA splicing factor SF2 influences $5^{\prime}$ splice site selection by activating proximal sites. Cell 62: 35-42.

Mamula, M.J., M. Baer, J. Craft, and S. Altman. 1989. An immunological determinant of RNase $\mathrm{P}$ protein is conserved between Escherichia coli and humans. Proc. Natl. Acad. Sci. 86: $8717-8721$.

Maniatis, T., E.F. Fritsch, and J. Sambrook. 1982. Molecular cloning: A laboratory manual. Cold Spring Harbor Laboratory, Cold Spring Harbor, New York.

Mattaj, I.W. 1989. A binding consensus: RNA-protein interactions in splicing, snRNPs, and sex. Cell 57: 1-3.

Reimer, G., I. Raska, U. Scheer, and E.M. Tan. 1988. Immunolocalization of 7-2 ribonucleoprotein in the granular component of the nucleolus. Exp. Cell Res. 176: 117-128.

Sambrook, J., E.F. Fritsch, and T. Maniatis. 1989. Molecular cloning: A laboratory manual, 2nd ed. Cold Spring Harbor Laboratory Press, Cold Spring Harbor, New York.

Topper, J.N. and D.A. Clayton. 1990a. Characterization of hu- man MRP/Th RNA and its nuclear gene: Full-length MRP/ Th RNA is an active endoribonuclease when assembled as an RNP. Nucleic Acids Res. 18: 793-799.

. 1990b. Secondary structure of the RNA component of a nuclear/mitochondrial ribonucleoprotein. I. Biol. Chem. 265: 13254-13262.

Winkelmann, G., M. Bach, and R. Lührmann. 1989. Evidence from complementation assays in vitro that U5 snRNP is required for both steps of mRNA splicing. EMBO /. 8: 31053112.

Yuan, Y., R. Singh, and R. Reddy. 1989. Rat nucleolar 7-2 RNA is homologous to mouse mitochondrial RNase mitochondrial RNA-processing RNA. I. Biol. Chem. 264: 1483514839. 


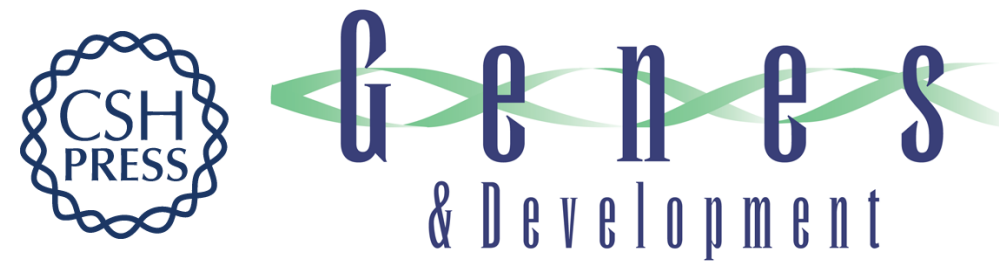

\section{Nuclear RNase MRP processes RNA at multiple discrete sites: interaction with an upstream $\mathrm{G}$ box is required for subsequent downstream cleavages.}

R Karwan, J L Bennett and D A Clayton

Genes Dev. 1991, 5:

Access the most recent version at doi:10.1101/gad.5.7.1264

References This article cites 29 articles, 11 of which can be accessed free at: http://genesdev.cshlp.org/content/5/7/1264.full.html\#ref-list-1

License

Email Alerting Service

Receive free email alerts when new articles cite this article - sign up in the box at the top right corner of the article or click here.

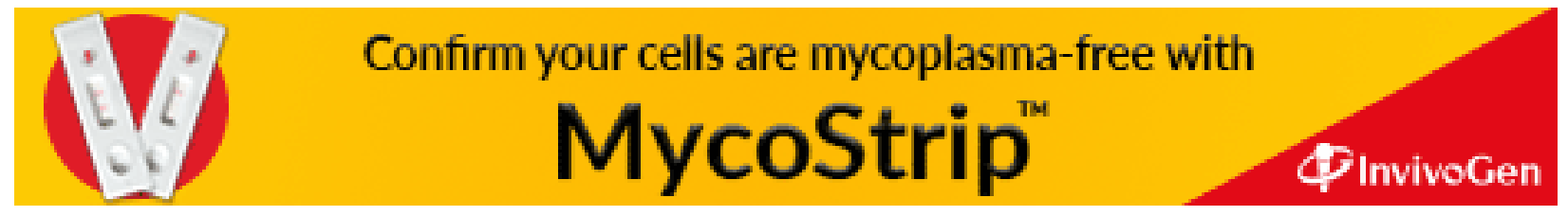

